
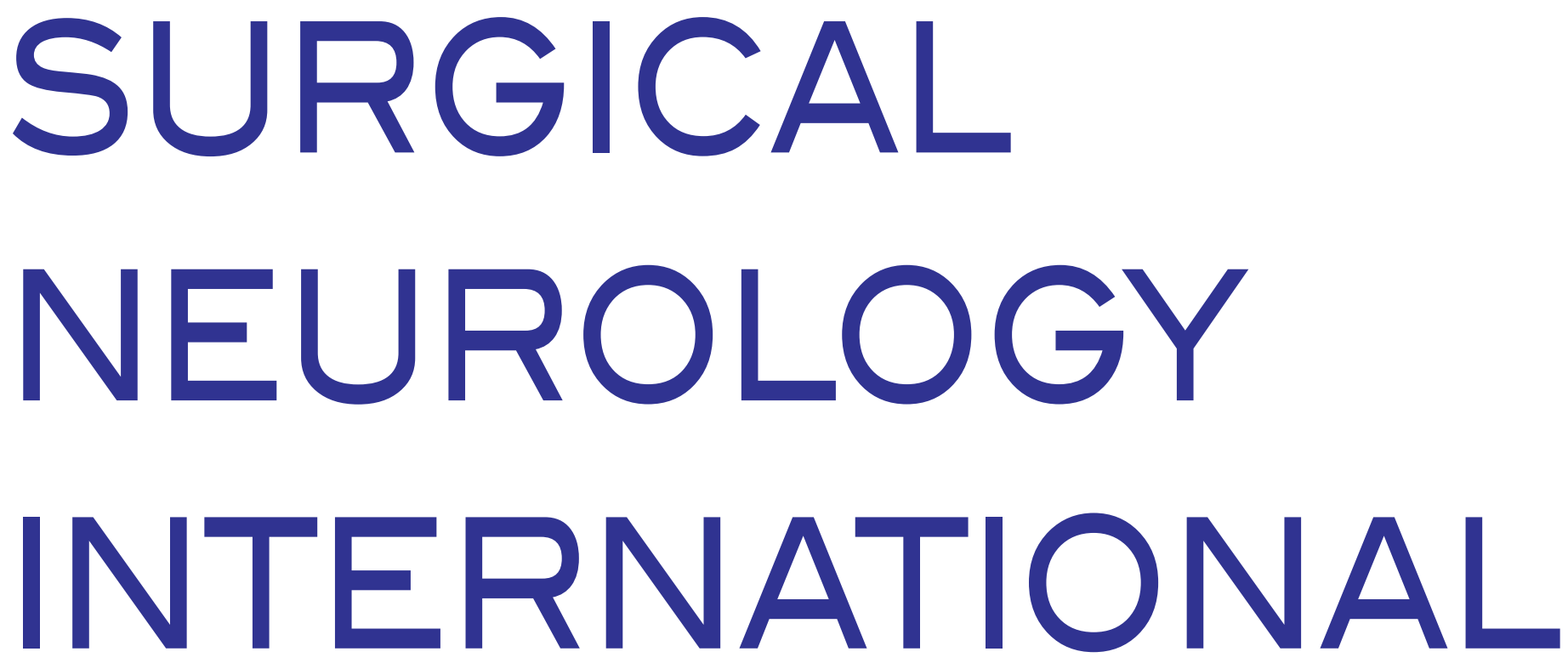

AN OPEN ACCESS, INTERNATIONAL JOURNAL
OF NEUROSURGERY AND NEUROSCIENCE Jan-Feb 2012 / Vol 3 / ISSUE 1 


\title{
Cranial nerve cavernous malformations causing trigeminal neuralgia and chiasmal apoplexy: Report of 2 cases and review of the literature
}

Nuno Miguel Pereira de Morais, António Lino Rodrigues Mascarenhas ${ }^{1}$, João Paulo Soares-Fernandes², José António Moreira da Costa

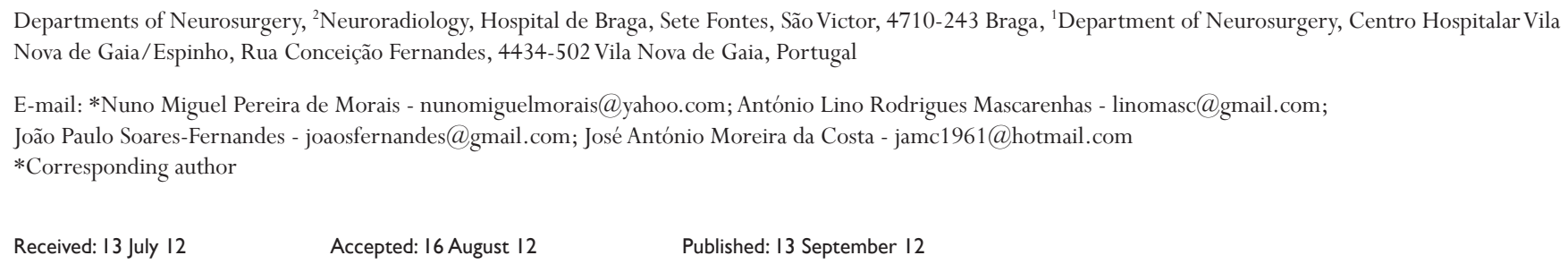

This article may be cited as:

Pereira de Morais NM, Mascarenhas AR, Soares-Fernandes JP, Moreira da Costa JA. Cranial nerve cavernous malformations causing trigeminal neuralgia and chiasmal apoplexy: Report of 2 cases and review of the literature. Surg Neurol Int 2012;3:105.

Available FREE in open access from: http://www.surgicalneurologyint.com/text.asp?2012/3/I/I05// 00864

Copyright: (c) 2012 de Morais NMP. This is an open-access article distributed under the terms of the Creative Commons Attribution License, which permits unrestricted use, distribution, and reproduction in any medium, provided the original author and source are credited.

\begin{abstract}
Background: Cavernous malformations (CMs) confined to the cranial nerves $(\mathrm{CN})$ are extremely rare lesions.

Case Description: The authors report 2 cases of $\mathrm{CMs}$, one involving the trigeminal nerve presenting with a 3 years history of a refractory right trigeminal neuralgia that was microsurgically resected by a retromastoid approach with resolution of the neuralgia; and another CM involving the chiasma with an abrupt onset of vision loss with acute intralesional bleeding that was removed through a right pterional approach with vision improvement.

Conclusion: Surgical resection is recommended in the context of progressive significant neurological deficit, emergency decompression as a result of recent hemorrhage for symptomatic relief or increase in size on serial magnetic resonance imaging (MRI).
\end{abstract}

Key Words: Cavernous malformation, chiasma, chiasmal apoplexy, cranial nerve, trigeminal nerve, trigeminal neuralgia

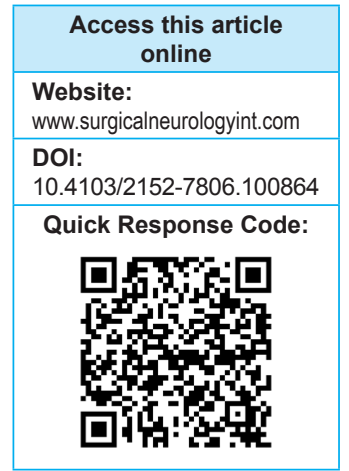

\section{INTRODUCTION}

Cavernous malformations (CMs) are vascular malformations that consist of thin hyalinized vascular channels without intervening brain parenchyma. CM constitute approximately 10-15\% of all vascular malformations. ${ }^{[4]}$ Their location is variable, with $70-80 \%$ having a supratentorial origin, followed by infratentorial location (15\%), within the spinal cord (5\%) and the cranial nerves $(\mathrm{CNs}) .{ }^{[14]}$ Twenty-seven cases of $\mathrm{CM}$ arising from the optic pathways $[2,10,13,20-22,24,25,28,30,32,34,38,39,41,44]$ and four cases of trigeminal nerve CM have been reported. ${ }^{[1,15,17,35]}$

\section{CASE REPORTS}

\section{Case 1}

A 49-year-old female patient presented to our hospital with a 3 years history of right trigeminal neuralgia in the territory of the first division of the trigeminal nerve refractory to the best medical therapy. Neurological examination was normal. Magnetic resonance imaging 
(MRI) showed multiple CMs, one of which located on the cisternal segment of the right trigeminal nerve [Figure 1]. We performed a right retrosigmoid craniotomy and total removal of the CM. Histopathological study was compatible with a CM. On the follow-up 28 months later the patient is pain and medication free.

\section{Case 2}

A 40-year-old female patient came to our attention with complains of sudden headache and vision loss. Examination revealed bitemporal hemianopia, diminished visual acuity in both eyes and nuchal rigidity. MRI showed multiple CMs, one of which localized in the optic chiasm, revealing recent bleeding [Figure 2]. The patient had undergone four previous craniotomies at another institution for removal of bleeding CMs in different locations without sequelae. The senior author (JAMC) decided to perform emergent surgical exploration through a right pterional craniotomy, removing the clot and the lesion. Histopathological examination was reported as a CM. On the follow-up, the vision improved and the patient is capable of reading and driving, but 11 years after the surgery a right homonymous hemianopsia persists.

\section{DISCUSSION}

CM incidence is roughly $0.4-0.8 \%$, they can be found in sporadic or familial form. ${ }^{[4]}$ In $40-60 \%$ of cases CMs are multiple and a familial inheritance is suggested. ${ }^{[8]}$ Three distinct gene foci on chromosomes 7p, 7q and three have been linked to familial CMs. ${ }^{\left[{ }^{[1]}\right.}$

Most $\mathrm{CN}$ CMs present with cranial nerve palsies, where others bleed resulting on subarachnoid hemorrhage.

Acute chiasmal syndrome or chiasmal apoplexy is a rare event, that can be caused by arteriovenous malformations and chiasmatic CMs and is characterized by abrupt vision loss and reduction of the visual field associated with a retroorbital headache. ${ }^{[31]}$

To the best of our knowledge, 69 cases of $\mathrm{CN}$ CMs
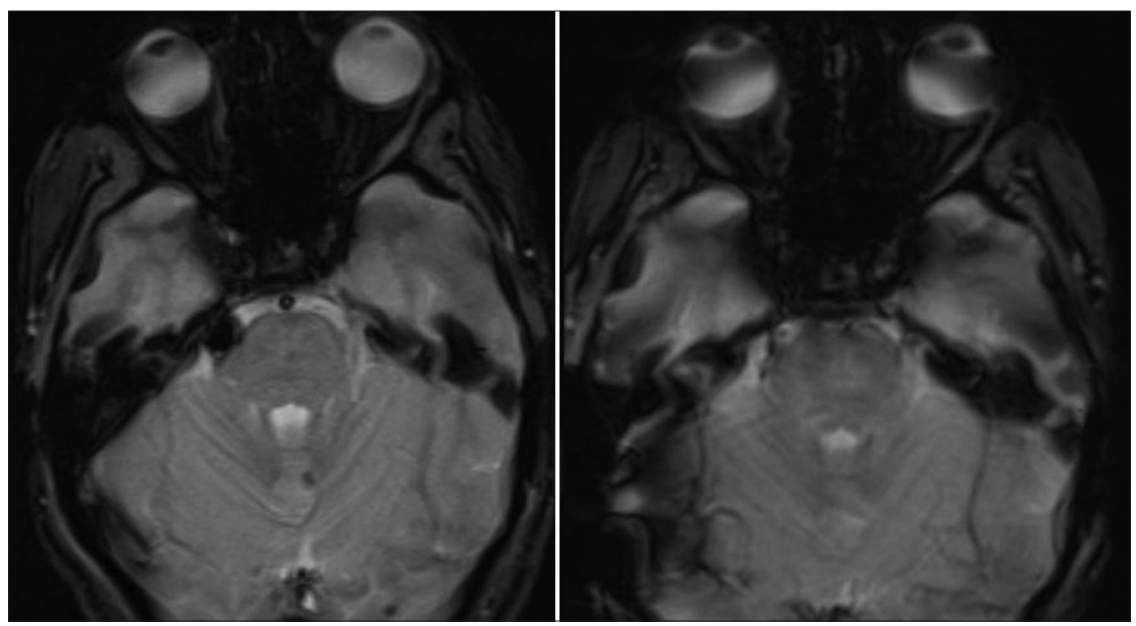

Figure I: Cerebral MRI. Left image: Preoperative axial gradient echo scan. Right image: Postoperative axial gradient echo scan

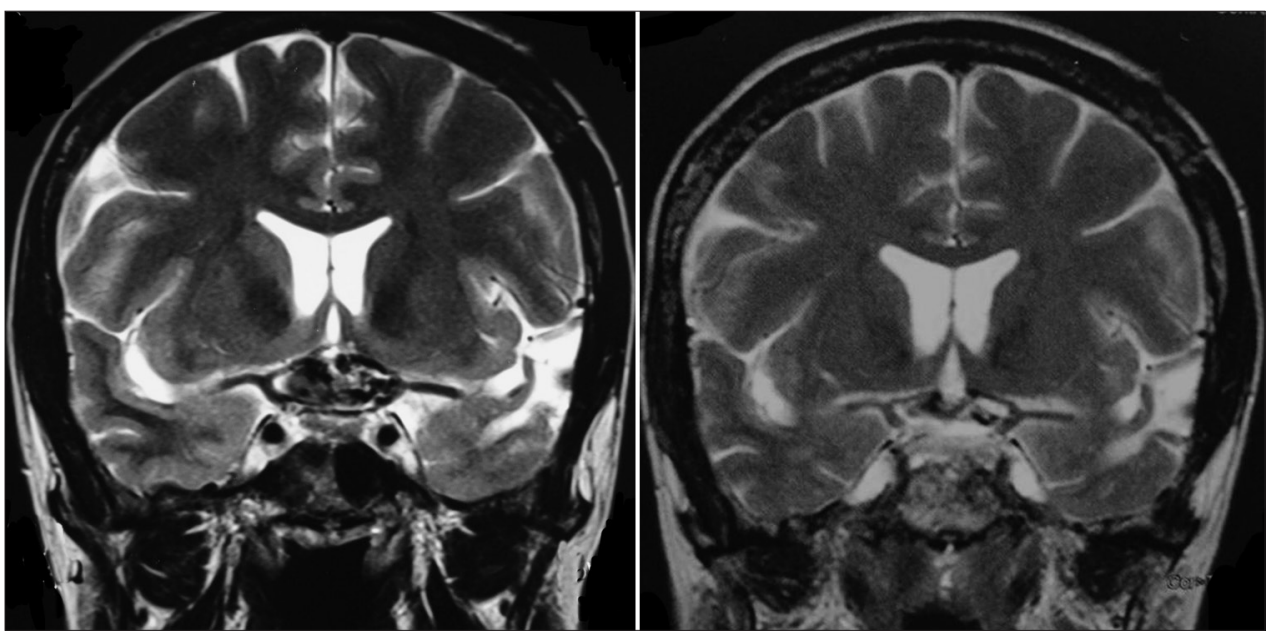

Figure 2: Cerebral MRI. Left image: Preoperative coronal T2-weighted scan. Right image: Postoperative coronal T2-weighted scan 
have been reported to date, namely in the III nerve $(5$ cases $),{ }^{[27,40,43,47,48]}$ IV nerve $(3$ cases $),{ }^{[33,45,46]}$ VI nerve (l case), ${ }^{[37]}$ cerebellopontine angle (27 cases, involving VII/VIII complex and other nerves not specified), ${ }^{[1,3,5,-7,9,16,18,19,26,29,36,42]} \mathrm{XI}$ nerve (1 case), ${ }^{[23]}$ and XII nerve ( 1 case). ${ }^{[12]}$

Twenty-seven cases of CMs of the optic pathways have been described, $[2,10,13,20-22,24,25,28,30,32,34,38,39,41,44]$ with some presenting with acute chiasmal syndrome or chiasmal apoplexy. The most used approach was pterional like the case presented. The chiasma CM case reminds us the urgency to decompress the chiasma to preserve and/or improve visual function.

Four cases of trigeminal $\mathrm{CM}^{[11,15,17,35]}$ have been previously reported, making our case of the trigeminal CN CM the fifth to be reported in the literature.

The natural history of CMs is unknown, however surgery is recommended for decompression as a result of recent hemorrhage for symptomatic relief (e.g., chiasmal apoplexy), to obtain a histological diagnosis, if there is a progressive significant neurological deficit or an increase in size on serial MRI. Subtotal removal can lead to recurrence, therefore total resection with preservation of $\mathrm{CN}$ function is the gold standard.

\section{CONCLUSION}

CMs are being increasingly detected as incidental lesions. Asymptomatic CN CMs should be managed conservatively and followed-up annually with MRI. ${ }^{[4]}$ According to our literature review, we recommend treating $\mathrm{CN}$ CMs only in the following situations: in the context of progressive significant neurological deficit, emergency decompression as a result of recent hemorrhage for symptomatic relief (e.g., chiasmal apoplexy) or increase in size on serial MRI.

MRI can be highly suggestive of CM, but definitive diagnosis can only be made by histological examination.

At present, the best management of $\mathrm{CN}$ CMs relies on the surgeon's personal experience and clinical judgment.

\section{REFERENCES}

I. Adachi K, Yoshida K, Akiyama T, Kawase T. Cavernous angioma of the vestibular nerve: Case report and literature review. Surg Neurol 2008;70:82-6.

2. Arrué P, Thorn-Kany M, Vally P, Lacroix F, Delisle MB, Lagarrigue J, et al. Cavernous hemangioma of the intracranial optic pathways: CT and MRI. J Comput Assist Tomogr 1999;23:357-61.

3. Babu R, Ransohoff J, Cohen N, Zagzag D. Cavernous angiomas of the internal auditory canal:A case report and review of literature. Acta Neurochir (Wien) 1994;129:100-4.

4. Batra S, Lin D, Recinos PF, Zhang J, Rigamonti D. Cavernous malformations: Natural history, diagnosis and treatment. Nat Rev Neurol 2009;5:659-70.

5. Bordi L, Pires M, Symon L, Cheesman AD. Cavernous angioma of the cerebellopontine angle: A case report. Br J Neurosurg 1991;5:83-6.

6. Bricolo A, De Micheli E, Gambin R, Alessandrini F, luzzolino P. Cavernous malformation of the internal auditory canal. A case report.J Neurosurg Sci 1995;39:153-8.

7. BrunoriA, Chiappetta F.Cystic extra-axial cavernoma of the cerebellopontine angle. Surg Neurol 1996;46:475-6.

8. Campbell PG, Jabbour P, Yadla S, Awad IA. Emerging clinical imaging techniques for cerebral cavernous malformations: A systematic review. Neurosurg Focus 2010;29:E6.

9. Capelle HH, Nakamura M, Lenarz T, Brandis A, Haubitz B, Krauss JK. Cavernous angioma of the geniculate ganglion.J Neurosurg 2008; 109:893-6.

10. Cerase A, Franceschini R, Battistini S, Maria Vallone I, Penco S, Venturi C. Cavernous malformation of the optic nerve mimicking optic neuritis. J Neuroophthalmol 2010;30:126-31.

II. ChoWS, Kang HS, Kim JW, Kee Park C, Kim JE. Cavernous malformation of the cisternal trigeminal nerve. Br J Neurosurg 20 I ; 25:339-40.

12. Chow M, Addas B, Sangalang V, Holness R. Cavernous malformation of the hypoglossal nerve: Case report and review of the literature. Can J Neurol Sci 2002;29:191-4.

13. Corboy JR, Galletta SL. Familial cavernous angiomas manifesting with an acute chiasmal syndrome. Am J Ophthalmol 1989;108:245-50.

14. D'Angelo VA, De Bonis C,Amoroso R, Cali A, D'Agruma L, Guarnieri V, et al. Supratentorial cerebral cavernous malformations: Clinical, surgical, and genetic involvement. Neurosurg Focus 2006;21:e9.

15. Deshmukh VR, Hott JS, Tabrizi P, Nakaji P, Feiz-Erfan I, Spetzler RF. Cavernous malformation of the trigeminal nerve manifesting with trigeminal neuralgia: Case report. Neurosurgery 2005;56:E623.

16. Escada P, Capucho C, Silva JM, Ruah CB, Vital JP, Penha RS. Cavernous haemangioma of the facial nerve.J Laryngol Otol 1997; I I :858-61.

17. Fehlings MG, Tucker WS. Cavernous hemangioma of Meckel's cave. Case report. J Neurosurg 1988;68:645-7.

18. Feiz-Erfan I,Zabramski JM, Herrmann LL, Coons SW. Cavernous malformation within a schwannoma: Review of the literature and hypothesis of a common genetic etiology.Acta Neurochir (Wien) 2006; 148:647-52.

19. Ferrante L, Acqui M, Trillo G, Antonio M, Nardacci B, Celli P. Cavernous angioma of the VIIIth cranial nerve. A case report. Neurosurg Rev 1998;21:270-6.

20. Ferreira NP, Ferreira MP. Optic nerve apoplexy caused by a cavernous angioma: Case report. Neurosurgery 1992;30:262-4.

21. Hankey GJ, Khangure MS. Chiasmal apoplexy due to intrachiasmatic vascular malformation rupture. Aust N Z J Med 1987;17:444-6.

22. Hassler W, Zentner J, Petersen D. Cavernous angioma of the optic nerve. Case report. Surg Neurol 1989;31:444-7.

23. Hazzard MA, Patel NB, Hattab EM, Horn EM. Spinal accessory nerve cavernous malformation.J Clin Neurosci 2010;17:248-50.

24. Hempelmann RG, Mater E, Schröder F, Schön R. Complete resection of a cavernous haemangioma of the optic nerve, the chiasm, and the optic tract. Acta Neurochir (Wien) 2007; 149:699-703.

25. Hufnagel TJ, Cobbs WH. Microangioma and optochiasmatic apoplexy. Description of an anatomo-clinical entity associating spontaneous hemorrhages of the anterior optic pathways and rupture of cryptic vascular anomalies. J Fr Ophtalmol 1988; I I:8I-4.

26. Iplikcxioglu AC, Benli K, Bertan V, Ruacan S. Cystic cavernous hemangioma of the cerebellopontine angle: Case report. Neurosurgery 1986; 19:64I-2.

27. Itshayek E, Perez-Sanchez X, Cohen JE, Umansky F, Spektor S. Cavernous hemangioma of the third cranial nerve: Case report. Neurosurgery 2007;61:E653.

28. Iwai Y,Yamanaka K, Nakajima H, Miyaura T. Cavernous angioma of the optic chiasm. Case report. Neurol Med Chir (Tokyo) 1999;39:617-20.

29. Kim M, Rowed DW, Cheung G, Ang LC. Cavernous malformation presenting as an extra-axial cerebellopontine angle mass: Case report. Neurosurgery 1997;40:187-90.

30. Klein LH, Fermaglich J, Kattah J, Luessenhop AJ. Cavernous hemangioma of optic chiasm, optic nerves and right optic tract: Case report and review of the literature. Virchows Arch A Pathol Anat Histol 1979;383:225-3I.

3I. Maitland CG, Abiko S, Hoyt WF, Wilson CB, Okamura T. Chiasmal apoplexy. Report of four cases. J Neurosurg 1982;56:1 18-22.

32. Malik S, Cohen BH, Robinson J, Fried A, Sila CA. Progressive loss vision. A rare manifestation of familial cavernous angiomas.Arch Neurol 1992;49: 170-3.

33. Manjila S, Moon K, Weiner MA, Cohen ML, Leigh RJ, Megerian CA, et al. Cavernous malformation of the trochlear nerve: Case report and review 
of the literature on cranial nerve cavernomas. Neurosurgery 2011;69: E230-8.

34. Marouka N, Yamakawa Y, Shimauchi M. Cavernous hemangioma of the optic nerve. Case report.J Neurosurg 1988;69:292-4.

35. Mascarenhas L, Magalhães F, Magalhães Z, Romão H, Resende M, ResendePereira J, et al. Cavernous malformation of the trigeminal nerve. Neurocirugia (Astur) 2006; 17:64-7.

36. Miyashita T, Hoshikawa H, Kagawa M, Mori N.A case report of facial nerve hemangioma. Auris Nasus Larynx 2007;34:519-22.

37. Moon KS, Jung S, Lee KH, Lee MC. Cavernous hemangioma of the abducens nerve: Clinical implication of duplicated variants: Case report. Neurosurgery 20II;69:E756-60.

38. Murai Y, Adachi K, Koketsu K, Teramoto A. Indocyanine green videoangiography of optic cavernous angioma - case report. Neurol Med Chir (Tokyo) 201 I;51:296-8.

39. Newman H, Nevo M, Constantini S, Maimon S, Kesler A. Chiasmal cavernoma: A rare cause of acute visual loss improved by prompt surgery. Pediatr Neurosurg 2008;44:4I4-7.

40. Ogilvy CS, Pakzaban P, Lee JM. Oculomotor nerve cavernous angioma in a patient with Roberts syndrome. Surg Neurol 1993;40:39-42.

4I. Ozer E, Kalemci O, Yücesoy K, Canda S. Optochiasmatic cavernous angioma: Unexpected diagnosis. Case report. Neurol Med Chir (Tokyo) 2007;47:| 28-3|.

42. Pappas DG, Schneiderman TS, Brackmann DE, Simpson LC, Chandra-Sekar B, Sofferman RA. Cavernous hemangiomas of the internal auditory canal. Otolaryngol Head Neck Surg 1989;101:27-32.

43. Park DM, Kim DH. Cavernous angioma of the oculomotor nerve.J Korean Neurosurg Soc 2005;38: 147-50.

44. Shkarubo AN, Serova NK, Tropinskaia OF, Shishkina LV, Pronin IN. Chiasmatic cavernoma [Article in Russian]. Zh Vopr Neirokhir Im N N Burdenko 2005;2:20-I.

45. Sindou $M$, GilgA,Vighetto A, Jouvet A. Cryptic angioma in the trochlear nerve: Excision of the invaded portion and successful repair with an autologous graft: Case report. Neurosurgery 1992;30:255-8.

46. Surucu O, Sure U, Mittelbronn M, Meyermann R, Becker R. Cavernoma of the trochlear nerve. Clin Neurol Neurosurg 2007; 109:791-3.

47. Wolfe SQ, Manzano G, Langer DJ, Morcos JJ. Cavernous malformation of the oculomotor nerve mimicking a partially thrombosed posterior communicating artery aneurysm: Report of two cases. Neurosurgery 20II;69:E470-4.

48. Yamada T, Nishio S, Matsunaga M, Fukui M,Takeshita I. Cavernous hemangioma in the oculomotor nerve. A case report.J Neurol 1986;233:63-4. 